\title{
Forest Product Industry and Engineered Wood Products: The Nigerian Experience
}

\section{${ }^{* 1}$ EKUNDAYO, OO; ${ }^{2}$ ARUM, C; ${ }^{3}$ OWOYEMI, JM}

\author{
${ }^{1}$ Department of Building, Federal University of Technology Akure, Nigeria \\ ${ }^{2}$ Department of Civil Engineering, Federal University of Technology Akure, Nigeria \\ ${ }^{3}$ Department of Forestry and Wood Technology, Federal University of Technology Akure, Nigeria \\ *Corresponding Author Email: ooekundayo@futa.edu.ng
}

\begin{abstract}
The forest product industry in Nigeria is barely surviving rather than thriving. Faced with a lot of challenges, the industry has witnessed the closure of many wood processing industries while a few are operating at low capacity. This paper examines engineered wood products and the outlook on wood and wood products in Nigeria. It discusses some of the challenges that have inhibited the growth of the industry and provides recommendations for reinventing the industry through development of modern value-added wood products for sustainable building construction.
\end{abstract}

DOI: https://dx.doi.org/10.4314/jasem.v25i1.14

Copyright: Copyright (C) 2021 Ekundayo et al. This is an open access article distributed under the Creative Commons Attribution License (CCL), which permits unrestricted use, distribution, and reproduction in any medium, provided the original work is properly cited.

Dates: Received: 02 October 2020; Revised: 26 November 2020; Accepted: 12 December 2020

Keywords: Collaboration; Engineered wood products; Forestry product industry; Glulam; Sustainability.

In view of verifiable threats to the natural environment, the need to drive development in the built environment along the path of sustainability in line with the United Nations Millennium Development Goals (MDGs) has necessitated the call for environmentally responsive practices in the built environment (Ortiz, et al., 2009; Pacheco-Torgal and Labrincha, 2013). Hence the focus on sustainable and renewable building and civil engineering materials. This ideology has come to stay as a corner stone that underpins the correctness of any developmental effort as touching the environment. The call for this paradigm shift comes on the heels of verifiable threats to the sustenance of earth's non-renewable resources and the overall environmental well-being (Ametepey and Ansah, 2014; Mehta et al., 2013). Nowadays, contemporary issues of research and development in construction materials revolve around priority areas such as: sustainability, energy efficiency, climate change and environmental friendliness (PachecoTorgal and Labrincha, 2013). The result of these is the advocacy for efficient use of natural resources, materials and technologies with low carbon foot prints. In this regard, an indefinite supply of renewable and sustainably managed forest resources and low embodied energy materials, methods and technology become imperative.

Wood as Sustainable Engineering Material: The material components of building and civil engineering works depend on the natural environment for supply.
Few of these materials have however proved to have an excellent environmental credential to meet today's drive for sustainable development. Key among them is timber. A sustainable building material is one that possesses notable features which include: environmental friendliness, affordability, availability, flexibility in usage, and durability. The appeal for timber construction the world over has therefore continued to grow. This is predicated on the need to utilize sustainable and renewable construction materials (Correal et al., 2014). Timber as a construction material possesses the above features and has proved to be renewable (Mehta et al., 2013). Its ability to sequester $\mathrm{CO}_{2}$, a high strength to weight ratio to reduce dead load, simplify foundation design, obviate the need for heavy lifting and hoisting equipment, low tooling and simpler construction techniques, has earned it the pride-of-place as a choice material for renewable construction (Mehta et al., 2013). Sustainably managed forest resources have proved to be renewable source of timber. Timber has thus been around far back in antiquity as an excellent structural material. It has offered mechanical properties desirable to engineers and designers for a wide array of applications. Its notable performance in flexure has yielded a variety of structural forms such as floor joist, and beams. Possessing remarkable tensile and compression capacity, a broad spectrum of structural timber elements are made possible. These include beams, columns of either sawn or composite timber, railway sleepers and roof truss members 
applied in both building and civil engineering structures. Furthermore, functional requirements stratify structural materials into grades of various degree of application based on standard material tests. Hence, various codes have agreed on a system of qualifying timber for various applications. Timber for structural application is thus usually stress graded both visually and mechanically (APA, 2012). However graded timber pieces possess a rare combination of functional requirements that makes wood a classic constructional material. These features includes durability, strength and lightness, remarkable thermal and acoustic performance, robust environmental credential, ease of fabrication and jointing ranging from mechanical fasteners to adhesives, flexibility of architectural forms and endless possibilities in geometry (APA, 2012; Porteous and Kermani, 2013). Nevertheless, the performance of timber as an ideal construction material is as good as the understanding of the handler. Most of the desirable features in timber are the making of the biological processes of the living tree (Thelandersson and Larsen, 2003). Unlike conventional materials like concrete or steel where material outcome at both microscopic and macroscopic level can be manipulated through chemical and industrial processes to suit specific applications, natural timber only lends itself to such manipulations in very limited ways. Being an adaptive material therefore, timber structures must be detailed and constructed with an understanding of the properties of wood and the effects of immediate environmental conditions such as moisture on those properties. Hence, timber is an excellent construction material to the extent its properties are understood by the designer or engineer.

Innovative Use of Timber: Engineered Wood Products $(E W P):$ The prominence of small diameter logs due to the decline in large diameter round logs is a global phenomenon. Unfortunately, it has consistently weakened the prospects of Forest and forestry products for structural application in Nigeria (Ogunwusi, 2012). This is so since the quality of logs bear directly on the performance of wood products for targeted purposes. This situation is however not peculiar to Nigerian but one that is so globally. What is however worrisome is the pace of action in adopting existing technologies to surmount these challenges as is the case in developed societies. In order to cope with the decline in quality log output and the associated cost while maintaining competitiveness in wood products as sustainable engineering materials, reconstituted wood, otherwise known as wood composites or engineered wood products (EWP) were developed. EWPs are a broad spectrum of wood based products targeted for structural application (Thelandersson,
2003). These are products made up of wood components bonded by a matrix of natural or synthetic resins (Barbu et al., 2014; Rowell, 2012). Also included are mechanically fastened wood components to mitigate defects in sawn wood (Porteous and Kermani, 2007). Furthermore, adhesively bonded wood products that offer structural support systems to buildings are included in the list (Stark, et al., 2010). The aim ultimately of EWP is to derive superior engineering properties, dimensional stability and products that are reliable under varying conditions of load.

Glued laminated timber: Sawn timber by its flexibility lends itself to innovation to yield superior performance materials such as glued laminated timber (GLT or glulam) as shown in fig 1. It is the nearest attempt at maintaining the beauty of natural wood. Where timber is adhesively bonded, the strength of the joint and its properties is like that of the wood (Thelanderson, 2003). This understanding is the basic rationale behind glulam. It is therefore, an engineered wood product (EWP) which consists of layers of stress graded timber horizontally glued up with grains parallel to each other using adhesives. It as an engineered beam glued up from selected wood pieces, or laminations prepared either in a straight or curved shape with the grain of all pieces aligned parallel to the longitudinal axis of the member (APA, 2018; Moody and Hernandez, 1997; Nadir and Nagarajan, 2014). According to Nadir (2014), it is an effective method for deriving higher performance properties from sawn timber.

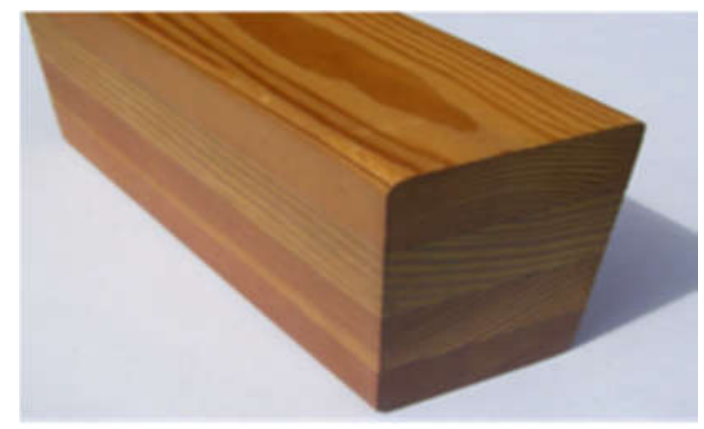

Fig.1: Glulam (Olorunisola, 2018)

History of glulam: The history of glued laminated timber dates back to 1893 in Switzerland where the first Patent was obtained and known as the Hetzer System. A notable structure constructed of GLT includes the auditorium in Basel, Switzerland. The use of glulam was then mostly suited for dry use as the adhesive in use was not applicable in conditions of water exposure (Moody and Hernandez, 1997). However, more recently, iconic glulam structures such as; the Cross rail station in Canary Wharf London 
(2015), the Metropol Parasol in Seville (2011), the curved grid-shell roof structures at the Centre and the Pompidou-Metz near Paris (2010), bear record to the growing global interest and popularity of EWPs among engineers and designers (Sebastian, Piazza, and Tomasi, 2016).

Advantages of glulam: The use of GLT offers numerous advantages including architectural freedom, efficient use of forest resources such as the use of merchantable and non-merchantable timber species and mixed species application. Furthermore, it offers limitless possibilities in member geometry, dimension and the fabrication of tapered structural elements. Similarly, glulam makes it possible to position higher performance materials in regions of higher stresses in beam elements thereby making material optimization possible. Finally, value chain addition to forestry products, sustainability and environmentally benign structural material are notable advantages. Current and past researches have shown engineering innovation in Engineered Wood Products (EWP) to improve the use of timber beyond the natural limitations so as to offer superior performance materials (Nadir and Nagarajan, 2014). Series of researches spanning several decades have continuously demonstrated the engineering capabilities of timber as a structural material (Yang et al., 2009). Glued laminated timber (Glulam or GLT have since emerged in developed societies to establish the structural use of timber for a wide array of building and civil engineering structural application (Nadir and Nagarajan, 2014; Yang et al., 2009).
Other engineered wood products: Bodig and Jayne (1982) developed a comprehensive classification of engineered wood products as shown in Figure 2 (Barbu et al., 2014). The term engineered wood products covers a wide array of wood based products made from veneers or strands peeled, chipped or sliced. These products are suited for construction purpose as structural materials (Lam and Prion, 2003). They are generally classified into Wood Based Panel Products, Structural Composite Lumber, Timber Based Products and Combination products as shown in Figure 2. Notable features of these products include; allowance in the Control and selection of processing and production parameters to yield properties superior to sawn wood, examination of properties on a larger scale at fiber level in contrast to sawn wood where it is investigated at cellular level, and property alteration by fiber rearrangement and stratification (Youngquist, 1999).

Wood based panel products: According to Youngquist (1999), wood based panels can be classified into five categories taking cognizance of physical organization. This classification is shown in Figure 2. Their end use requirement is achieved by fiber rearrangement, density variation and type of adhesive resin used. Plywood is generally suited for both structural and non-structural purpose while other panel products such as particle board, hard board and medium density board (MDF) are generally of limited structural application. Plywood is classified into industrial or construction class and decorative class (Youngquist, 1999).

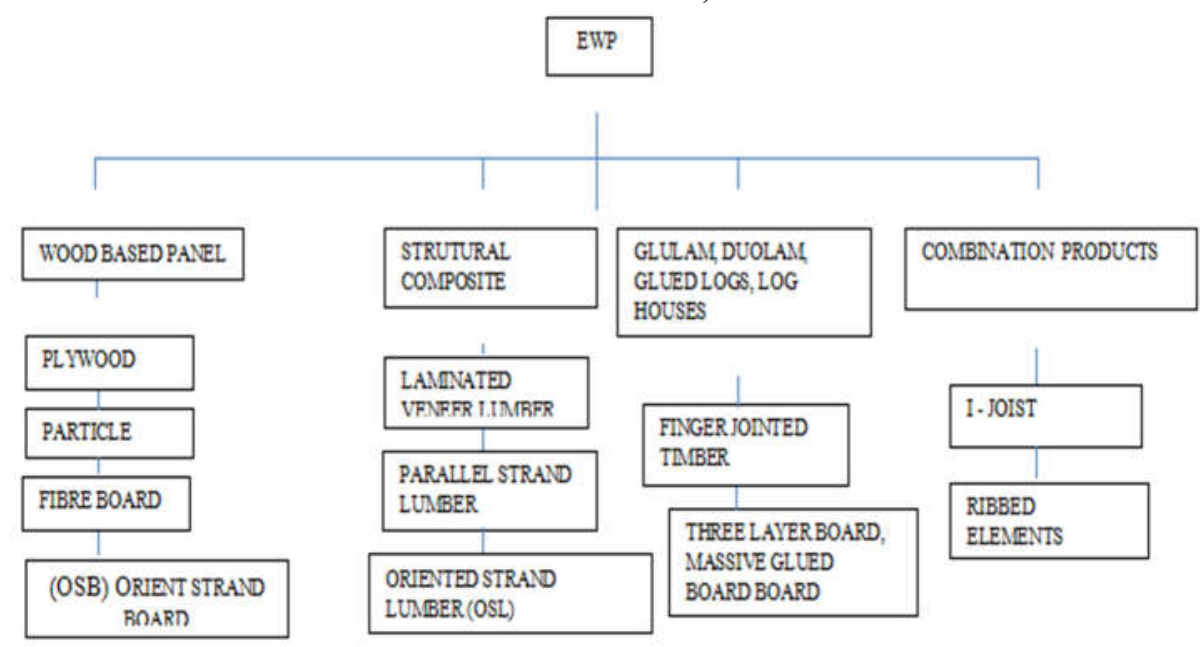

Fig 2: Classification of engineered wood products (Bardu et al., 2014)

Structural composite lumber: The American Plywood Association, (APA) classifies under a generic name a wide variety of engineered wood products known as Structural composite lumber (SCL). Structural composite lumber is a notable innovation in wood engineering developed to bridge the deficit of quality wood supply due to the devolution of forests resources both in quality of wood and the available sizes. EWP in this class include wood products such as Oriented strand lumber (OSL), Parallel strand lumber (PSL), 
Laminated veneer lumber (LVL) and Laminated strand lumber (LSL). These materials are produced from layers of dried and graded wood veneers, strands or flakes using adhesives resistant to moisture. SCL is produced as billets with grains usually oriented in the same direction and can be re-sawn to sizes that match the end use requirement. Structural composite lumber is defect free and characterized by strength, homogeneity, and consistency of the material properties which makes it superior in performance to natural sawn wood. SCL products are reported to be an economical and sustainable application of forest resources as the size and age of the trees available have little or no effect on the dimensions and mechanical properties of the end products. The structural applications include headers, beams, joists, studs, column and rafters. A notable difference in SCL products is in the length to thickness ratio $(\mathrm{L} / \mathrm{T})$ of the various types. PSL has L/T ratio of 300,150 for LSL and 75 for OSL.

State of the art: Engineered Wood Products Research and Development in Nigeria: For too long, both the academia and construction industry in Nigeria have looked away from the forestry sector as a viable source of material for extensive structural application beyond the typical roof and form work application. Therefore, many of the researches in structural materials have paid little attention to the use of timber for structural purpose. Most of the few studies carried out so far have been on sawn timber (Abubakar and Nabade, 2013; Aguwa, 2013; Idris et al., 2016; Kaura, et al., 2015; Kelechi et al., 2014). Only a minuscule amount of that category has probed the use of local species for engineered wood products such as glued laminated timber (Ezeagu, et al., 2015). There is need for studies that would examine the mechanical and physical behavior of glued laminated beam elements for structural application using local timber species under various environmental conditions. Understanding the behavior of engineered timber products like glued laminated timber using local species is essential for several reasons. First, the various nuances in properties of interest peculiar to native species can be characterized and factored into predictive models. Secondly, reliability evaluation can be more specific, realistic and dependable. Similarly, this can reveal information necessary to overcome challenges associated with the organic structure of sawn timber such as: unpredictable load responses, limitations in dimension and strength due to the presence of knots, property variations along its three mutually perpendicular axes within and between species. These have limited the use for structural purpose as it is less attractive to engineers and designers, as compared to conventional materials like steel and concrete. The practice of structural timber construction using engineered wood products such as glued laminated timber is well established internationally in developed societies. However, research into engineered wood products is rather inactive in Nigeria. Consequently, there is presently no known document for characteristic values of reference material properties (bending strength, modulus of elasticity in bending and density) or uncertainty models for glued laminated timber of any local species to enable reliability analysis of timber structures and computer modeling. Similarly, local timber species have no designated strength class to enable limit state design. The only existing standard is the Nigerian code of practice for use of timber NCP (2). It is expected that this standard developed on BS5268- the permissible stress method of design is overdue for review so as to be in line with EC 5- limit state design method as it is internationally (Abubakar and Nabade, 2014). Similarly, there is no data to inform computer modeling as touching the behavior of glued laminated timber beams of Nigeria species. In actualizing reliable wood based structural design in Nigeria, it is expected that characteristic values of reference material properties be obtained through laboratory test programs. This is particularly germane for two reasons. First, considering that timber is non homogenous between and within species and secondly, due to this property variance, international codes can only be applied with caution when dealing with local species that have no established data for their properties. Given the foregoing, test programs are required with the view to generating values of reference material properties to enable the development of uncertainty model for predicting bending strength of glued laminated timber with special reference to timber of Nigerian origin and grading the same into the relevant strength classes. Furthermore, the affinity of local species for various synthetic resins for structural use has not been verified in terms of joint efficiency through block shear test which is critical in glued laminated timber elements. It is noteworthy that the mechanical and physical properties of timber species such as; Southern pine (Pinus spp.), Douglas fir (Pseudotsuga menziesii), larch (Larix occidentalis), and Norway spruce species have been examined (Robert and Roland, 1995; Suhaimi, et al ., 2000; Wan et al ., 2011). Mechanical behaviors of many species such as Abura (Aguwa, 2013), Strombosia pustulata, Macrocarpa bequaertii, Nauclea diderrichii and Entandrophragmacy clindricum have similarly been studied Abubakar and Nabade, 2013). However, these studies pertain either to glulam elements of foreign timber species or simply of sawn local timber species. Rarely is there any research on glued laminated timber beams using Nigerian timber species. Moreover, the few studies on 
glulam of indigenous timber species have only considered the use of polyvinyl acetate glue which is not a structural adhesive (Ezeagu et al., 2015; Ekundayo and Alake, 2018). The suitability of other synthetic glues on local species and within the context of the environmental conditions in Nigeria in line with NCP2 of 1973 has not been studied. The implications of this is the lack of sufficient inquiry into the structural capabilities of home grown timber species as glued laminated timber structural elements thereby obscuring the understanding necessary for setting performance requirements under local environmental conditions which can influence mechanical properties, integrity of glue line and the joint efficiency of glued structural elements using different synthetic glues. Since the problem of property variation is common to every timber species, performance standards of foreign timber species cannot be applied head-on to local species. Consequently, it is pertinent to extensively study local species for their behavior as glulam elements.

Domesticating the requisite technology: The need to domesticate a green approach to construction underpins the necessity for a diligent inquiry into timber construction. It becomes particularly germane considering the benefits derivable from timber construction. Some of these include speed of construction, low embodied energy and environmental safety. More specifically, the need to profile timber species of local origin in line with modern approach to timber construction is beneficial for computer modeling development which would aid insight into local timber as structural elements and also reduce the need for destructive methods of testing. In furtherance, the information gathered would aid the Limit state design approach for code development for timber construction in Nigeria. The forestry products industry in Nigeria is in dire need of re-positioning. However such attempts would not be possible except it is preceded by targeted R\&D efforts by concerned stockholders for value addition in forestry products as robust structural engineering materials. However this would be unattainable amidst the seeming aloofness between industry and academia. A deliberate collaboration is hence required.

Challenges of timber utilization in Nigeria: the Historical Profile: Perhaps one of the most instructive insights into the historical profile of the forestry industry in Nigeria is the Aruofor- FAO report of year 2000. There the fundamental issue that plagues the forestry sector was clearly underscored- the lack of systematically collected and reliable statistical data. Little wonder the sector is barely surviving. This is in sharp contrast to what is obtainable in many developed societies where timely and reliable data have helped to reinvent the forestry sector. Many of the reports on the development of forestry sector in Nigeria have shown that the sector is on a downward spiral in terms of its productivity. The bane of this trend has generally been lack of concerted efforts by policy makers at reinventing the sector to one that is dynamic with the changing times. Several departments and agencies are reported to be saddled with the responsibility of data collection in the forestry sector. However many of these agencies have been incapacitated by lack of sufficient funds. Similarly, divergent interest among these agencies has made it impossible to synthesize the data into actionable policies that would drive innovation. Generally, subsectors in the industry such as the wood product sector had no record of evolving a common front to facilitate developing new wood composites product lines. The Forestry product industry (FPI) in Nigeria is broadly made up of the formal and informal sector. It generally comprises various subsectors namely; furniture saw mills, ply and veneer mills, particle boards, safety matches and timber door products (Aruofo, 2000; Ogunwusi, 2012). This is in sharp contrast to the Canadian FPIs which has only three subsectors ("Overview of Canadian's forestry industry", 2016). The industry in Nigeria has witnessed an era of boom but is currently faced with a myriad of challenges and as such is seen to be barely surviving rather than thriving. A fundamental issue has been the drop in capacity utilization across most of the sub sectors particularly those closely linked to the construction industry (Ogunwusi, 2014). The formal sector, which has capacity to process wood and yield superior products through mechanized methods of operation presently, is in tussle with the challenge of raw materials supplies. This is due to decline in quality round logs that initially populated the forest and the resultant low conversion rate due to obsolete technologies vis-à-vis the present state of forest resources; this problem is not peculiar to Nigeria (David and Larry, 2006). However, there has been no sufficient report in literature that identifies market shifts and opportunities these challenges present locally. The history of wood processing and utilization in Nigeria has witnessed the establishment of several wood processing companies (WPC) in the formal sector when the Nigerian economy made major gains from the FPI. Situated within easy reach to rain and swamp forest locations in Nigeria, some of these WPCs were state owned such as; Seromwood Industries Limited, Calvenwood Veneer and Plywood and Wood Complex Ltd, all located in Calabar. Similarly, in Akure are: Olukayode Sawmill (Nig) Limited, Soarse Wood and Timber, Premier Timber industries and Omoniyi Sawmill. Furthermore, there are Nigeria-Romanian Wood 
Industry, Ondo, Amo Sawmills in Ibadan, Epe Plywood Company Limited, and Wood land timber in Lagos State. In the South -South region there is African Timber and Plywood, Sapele in Delta State and Iyayi Group of Companies in Benin City. The lack of sustainable forest management practice has led to the demise of the vibrancy of some of the industries. On the other hand, the informal sector comprises cottage industries run by craftsmen such as pestle makers, carvers and tooth pick manufacturers (Ogunwusi, 2014). The FPIs were largely extractive; value- added products such as wood composites during the boom did not develop beyond particle board, ply wood and veneer. It is unfortunate that the era did not witness the development of other engineered wood products such as glued laminated timber, parallel strand lumber and the likes. An opportunity was therefore missed to not only closely link the construction industry and the forestry industry on a scale much larger than it was and currently is, but also to reinvent the FPIs for the realities of a paradigm shift in wood consumption that was to follow. In developed climes, the construction industry is a ready market for value- added products such as EWPS. This synergy may have provided the impetus to drive sustainable management practices in both industries. It would appear that the construction industry in Nigeria is generally a low consumer of wood composites as there is no record of large deployment of these classes of materials despite the derivable benefits. Furthermore, Ogunwusi (2014) reported that the number and production capacity of integrated mills such as the ply and veneer mills have been on the decline with the demise of prime logs in forestry resources. The particle board mills have similarly lost the competitive edge to foreign products due to low quality and production capacity and the associated high capital input. The major challenge facing the forestry industry in Nigeria is that it is largely extractive and not value- addition driven.

Engineered Wood Products: An Opportunity for Forestry Product Industry Reinvention: EWP such as glued laminated timber have advantages which if exploited, can offer an opportunity for developing and expanding market opportunities both locally and internationally, and as well engender the emergence of new industries or a reinvented FPI to drive valueadded products. There are evidences to show that formulating and enforcing actionable policies towards sustainable management of the nation's forest resources would facilitate the necessary alliance between forestry and the construction industry, if the tenets of sustainability would be entrenched ("Forest products and applications", 2017). The fact remains that even though prime logs have become grossly over exploited (Ogunwusi, 2012), there are literary evidences to show that the waste generated from sawmill can still be developed into high quality fiber products. Similarly, the technologies of EWPs make it possible to optimize the existing logs in the forest resources (David and Larry, 2006). These advantages ensure that high quality fiber products can still emerge from low quality raw material. Furthermore, it makes it possible for FPIs to retool and reinvent themselves. Furthermore, there would be a resultant increased demand for round logs over a wider spectrum of lumberable timber species. Nigeria has a long history of limiting the use of timber for construction largely to sawn timber. This trend made demand for a few species to surge to the point of over exploitation and the closure of many mills with decline in quality of forest harvest. However, the fact remains that the future of timber utilization for structural purpose lies in the ability to adopt best practices in timber value chain from sustainable forest management to valueadded products like EWP. While the technology for EWPs is not native to Nigeria or to many of the developed nations where it is practiced, technology transfer remains the method for adopting the technology.

Engineered Wood Products and Adaptive Silvicutural Practices: Decline in forest resources and the associated drop in capacity utilization of the related subsectors is by no means a Nigerian experience alone. Many developed societies have similar surveys that reveal decline in forest resources and the range of products that were obtainable (David and Larry, 2006). However, while the trend appears to be widespread, the strategy adopted in silvicultural practices the world over is not, particularly in Nigeria. Remarkable changes have been made in forest management strategies in Canada, Australia and the United States. Many of these changes have been motivated by the wide product range that EWPs afford. It is reported that many of the existing FPIs had to retool to align with the possibilities in EWPs and at the same time maintain competitiveness. Interestingly, the market prospects in EWPs has not only necessitated innovativeness among subsector players, but has also significantly driven innovativeness right through to the raw material base, that is, the change in forest management practices. According to David and Larry (2006), part of these strategies focus on genetic engineering to reduce the rotation time of trees. Similarly, quite apart from the destructive method of testing widely practiced in Nigeria which limits property investigation to laboratories, innovative modern forest practices have adopted the non-destructive method of testing to monitor stiffness properties in standing trees so as to 
match the trees to fell with the expected mechanical property of the intended wood composite (David and Larry, 2006; "University of Washington, College of forest resources", 2007). Methods that assess the elastic properties of standing tress include scattering based techniques and defect identifying ultrasonic tomography images (Bucur, 2005).

Paradigm Shift in Wood Product Consumption: The Nigerian construction industry largely consumes traditional timber products. The taste for value-added products has no strong presence in the built environment. According to Aruofor (2000), the major wood products consumed in Nigeria are Sawn-wood, plywood and particle board. Plywood and particle board being the only value- added wood products closely related to the construction industry. Wood consumption in contemporary times has left the realms of the traditional where sawn wood was in vogue to an era where several lines of value -added products have been developed from both primary and secondary wood processing waste. The Canadian FPI, for example is the largest in the world. It has been able to develop value added products in EWPs and expand market opportunities in the construction industry which is the largest consumer of EWPs. Next to Canada is the Swedish FPIs ("Overview of Canada's forest industry", 2016). The construction industry in these climes have been identified as a sector that gives the market thrust for the consumption of value- added wood products such as EWPs. This experience is similar in Australia and the United States of America ("Meeting future market demands", 2015; "Overview of Canada's forest industry", 2016; Volsky, 2011). Conversely, the construction industry in Nigeria has not been exposed to EWPs at a scale that would open up market opportunities for this class of value-added wood products to drive domestic consumptions in ways that would transform FPIs from merely surviving to thriving. A probable reason for this could be a combination of two things: widespread lack of interest in wood, and lack of knowledge of EWPs among engineers, architects and designers in adopting wood and value-added wood products for structural purpose. A possible reason for this trend could be traced to biases in curriculum where teaching and learning emphasizes some construction materials such as concrete and steel over others such as wood and other innovative materials.

Engineered wood products may still not be popular among many professionals. For many, it would seem that the knowledge of wood in construction is still colored by the deficiencies of natural sawn logs. If that were not the case, given the advantages, there would at least have been figures to show the consumption of engineered wood featuring among import commodities for the construction industry similar to other materials like steel and cement. According to Iwuoha (2013), timber still features among nine top selling imported construction materials only due to shortage of local supplies; it however did not feature as EWPs. International FPIs that are on the cutting edge are doing so leveraging engineered wood products. The knowledge of design in engineered wood products needs to be pursued more vigorously at a level that would at least popularize the knowledge among emerging professionals in the built environment. Similarly, it should be taught in mandatory courses for professionals in the built environment as a way to stimulate interest, awareness and a ready market for consumption of EWPs in the construction industry. Structural Wood based design and especially design in EWPs it would seem has not received deserving attention other conventional materials like concrete and steel receive. At this point, collaboration between academia, construction industry and FPIs becomes necessary.

Pan- Industrial Collaboration: Moving forward, the Nigerian FPIs have to adopt the necessary restructuring to advance the frontiers of wood products beyond the traditional use of timber. There are contemporary realities in silvicultural practices and international markets for value- added wood products that can cope with short rotation harvest cycles. In view of these, there is need for the Nigerian FPIs to restructure and retool. Much of the decline in capacity utilization in the existing mills could be reversed applying the needed transformation in the sector. Disjointed and ad-hoc efforts especially in statistical records and the operational strategy of FPIs in Nigeria could be said to be the bane of this sector (Aruofor, 2000). The world over, thriving FPIs have advocated the adoption of forestry industrial hubs as a strategy to improve their operational efficiency. Ogunwusi, (2012) had also made similar calls. It would take a conglomeration of various sectors to revamp the ailing FPIs in Nigeria. In order to revamp the FPI, it is pertinent that new high value- added wood products with a ready domestic market be developed. To achieve this end, there would be need for interindustry cooperation across various sectors including but not limited to; the academia, construction and various subsectors of the Forestry industry particularly those charged with the responsibility of forest management. Collaboration is necessary to aid the development of a common front by the allied sectors in securing funds to facilitate R\&D necessary to reposition the ailing forestry sector. It would help to develop a cohesive industrial hub around forest and forestry products where there would be corporation and market opportunities among the presently 
disjointed companies. It would herald an era of profitable collaborations within and between related sectors. Furthermore, documentation of robust and coherent statistical records is needed to drive future innovation. Aruofor (2000) had reported a lack of coherent and concerted efforts in tracking the performance of FPIs. According to him, forestry statistics especially on wood products are collected in ways not well organized or systematized. Hence, it is difficult to adopt such data for planning so as to engender efficiency in the operational strategy of the entire sector. This submission is an indication of lack of collaboration among allied sectors. Consequently, wood processing in Nigeria generates a lot of waste that could have been converted into several lines of products were it not for the lack of industrial hubs in the sector.

Conclusion: The Nigerian FPI is neither dynamic nor organized. The demise of the sector was due to lack of adoption of innovative value added wood products to strongly link it to a thriving construction industry. Research efforts in this sector is grossly inadequate. Hence the use of wood and wood products still remain largely rudimentary. The adoption of EWPs is the way to go in optimizing the existing forest resources. R \& $\mathrm{D}$ components can be driven by academia- industry collaboration. Professionals in the built environment must be sensitized on the merits of value added wood products for structural application.

\section{REFERENCES}

APA (2012). The Engineered Wood Association. Standard for performance-rated cross laminated timber. ANSI/APA PRG-320, Tacoma, WA.

APA (2018). Glulam Retrieved from www.apawood.org/glulam.

Abubakar, I; Nabade, A (2013). Physical and Mechanical Properties of Some Common Nigerian Timber Species Based on Limit State Design Approach. Stu. Civ. Eng. Arch. 2 (4).

Abubakar, I; Nabade, A (2014). Bending Strength Classification of Some Common Nigerian Timber Species. Jordan. J. Civil Eng. 8 (2),

Abubakar, I; Magaji, S (2016). Reliability Analysis of Timber Roof Truss Systems using Genetic Algorithm. Glo. J. Res. Eng. 16(3): 22-30.

Aguwa, J (2013). Structural Reliability of the Nigerian Grown Abura Timber Bridge Beam Subjected to Bending and Deflection Forces. Nig. J. Tech, 32(2), 241-252.
Ametepey, SO; Ansah, SK (2014). Impacts of construction activities on the environment: the case of Ghana. J. Const. Prj. Mgmt. Inno. 4(1), 934948.

Aruofor, RO (2000). Review and improvement of data related to wood-products in Nigeria. A report submitted to FAO/EU on data collection and analysis for sustainable forest management in ACP countries-linking national and international efforts, available at: www.fao.org/DOCREP/004/X6762E/X6762E00. HTM.

Barbu, MC; Reh, R; Irle, M (2014). Wood-based composites Reas. Dev. Wood Eng. Techn. (pp. 145): IGI Global.

Bodig, J; Jayne, BA (1982). Mechanics of wood and wood composites.

Bucur, V (2005). Ultrasonic techniques for nondestructive testing of standing trees. Ultrasonics, 43(4), 237-239.

Correal, JF; Echeverry, JS; Ramírez, F; Yamín, LE (2014). Experimental Evaluation of Physical and Mechanical Properties of Glued Laminated Guadua angustifolia Kunth. Constr. Buldg. Mat. $73,105-112$.

David, B; Larry M, (2006): The Future of Wood Products and How this May Affect Small Woodland Owners.

Ezeagu, C; Eromosele, A; Okoro, H; Chukwujekwu, U; Emetomo, T (2015). Flexural Strength of Solid and Glue-Laminated Timber Beams. Am. J. Eng. Sci. Techno. Res., 3(1).

Forest products and applications. (2017). Retrieved from www.nrcan.gc.ca

Iwuoah, JP (2013). Building and Construction materials. Retrieved from http:/www.smallstarter.com/browse ideas/building-and-construction-materialsbusiness-in-Africa.

Kaura, J; Abubakar, I; Aliyu, I. (2015). EN 338 Strength Grade and Uncertainty Models of Material Properties for Nigerian Grown Terminalia Superba (White Afara) Timber Specie. Nig. J. Techno. 34(1), 21-27. 
Kelechi-Asumba, S; Uche, O, (2015). An Investigation on the Engineering Properties of Higher and Lesser Known Timber Species in Kano Market. Nig. Metall. Soc. Pp 71-75

Lam, F; Prion, HG (2003). Engineered wood products for structural. Timber Engineering, Wiley New York, p.81

Meeting future market demands Australia's Forest Products and forest industry. (2015) www.agriculture.gov.au/SiteCollectionDocuments /forestry/fiac-issues-paper.docx

Mehta, M; Scarborough, W; Armpriest, D. (2013). Building construction: principles, materials, and systems (pp.817-877): Pearson Prentice Hall Ohio.

Moody, RC; Hernandez, R. (1997). Glued-laminated timber. Forest Product Laboratory. USDA Forest Service. Madison, Winconsin.

Nadir, Y; Nagarajan, P. (2014). The behavior of horizontally glued laminated beams using rubber wood. Const. Bldg. Mat. 55, 398-405.

Obucina, M; Gondzic, E; Smajic, S (2014). The Influence of Amount of Layer on the Bending Strength by Longitudinal Finger-jointing Wood Elements. Procedia Eng. 69, 1094-1099.

Ogunwusi, A. (2014). The forest products industry in Nigeria. Afr. Res. Rev. 6(4), 191-205.

Olorunnisola, AO (2018). Design of Structural Elements with Tropical Hardwoods. Springer. p. 82
Ekundayo, OO; Alake O. (2018). Study on the bending strength of Solid and Glued- laminated timber from three selected Nigerian wood species. J. Civ. Environ. Res. 10(6) pp.19-27

Ortiz, O; Castells, F; Sonnemann, G. (2009). Sustainability in the construction industry: A review of recent developments based on LCA. Const. Bldg. Mat., 23(1), 28-39.

Overview of Canada's forest industry. (2016) Retrieving from www.ncran.gc.ca.

Thelandersson, S; Larsen, HJ (2003). Timber engineering: John Wiley and Sons.

Vlosky, R P (2011). A Comparison of the Primary and Secondary Wood Products Sectors in Louisiana. Wood Industry/Drvna Industrija, 62(3)

Yang, TH; Wang, SY; Tsai, MJ; Lin, CY (2009). The charring depth and charring rate of glued laminated timber after a standard fire exposure test. $B d g$. Environ. 44(2), 231-236.

Youngquist, JA (1999). Wood-based composites and panel Products. In Wood handbook: Forest Products Laboratory $\bullet$ United States Department of Agriculture Forest Service - Madison, Wisconsin Pp. 10.1- 10.31,113. 